\title{
SUPPLEMENT TO THE
}

\section{BRITISH \\ MEDICAL \\ JOURNAL}

\section{LONDON SATURDAY MAY 11948}

\section{MEDICINE AT CAMBRIDGE}

BY

\section{H. WHITTLE, M.D., F.R.C.P.}

We publish below some notes on the University of Cambridge and the Medical School which may be of interest to members of the Association attending the Meeting.

The town of Cambridge probably owes its origin and importance to its strategic position as a fort (Castle Hill) guarding the crossing of the river over or through which lay the main line of communication between the Midlands and the Eastern Counties. To the north below this crossing were the relatively impassable Fens, though the river was navigable and Cambridge, until quite recent times, a port in daily communication with the sea via King's Lynn and the Wash. There is plenty of evidence that even before the twelfth century monasteries existed in or near the present site of the town. St. Rhadegunds was a nunnery standing where Jesus College now stands, and there are still remains of the old buildings. Of Barnwell Priory little is left, but the delightful Lepers' Chapel with some wellpreserved Norman work marks the site, close by the bridge where the Newmarket Road crosses the railway a mile out of the town.

It seems more than likely that the monasteries were the centres of study and teaching in the neighbourhood for several centuries, and so it was that the place was gradually sought out as a seat of learning. A "grammar school" may well have preceded the appearance of the colleges, but there is no doubt that the collegiate system proper was started by Hugh de Balsham in 1284 when he founded St. Peter's College, now Peterhouse. There followed Michael House (1324) and King's Hall (1337), both later absorbed into Trinity College, the former to become part of the kitchens. Then came in fairly rapid sequence Clare Hall (1326), Pembroke Hall (1347), Gonville Hall (1348), Trinity Hall (1350), and Corpus Christi College (1352). Nearly a century elapsed before the foundation of King's College (1441), and Queens' College (1448), the latter in the plural because it was, founded by two queens-Margaret of Anjou, wife of Henry VI, and Elizabeth Widvile, wife of Edward IV. There followed St. Catharine's (1475), Jesus (1496), St. John's (1511), Magdalene (1542), Trinity College (1546), Emmanuel (1584), and Sidney Sussex (1594). There is another long gap, over two hundred years, before Downing College (1800), and then follow the two women's colleges, Girton (1872) and Newnham (1875), and finally Ridley Hall (1881) and Selwyn (1882).

The older colleges are of great interest by reason of both their history and their buildings. Queens' has its early association with Erasmus (1510), after whom are named the turret and rooms below on the south side of the college; it has also the serene and mellow beauty of the Cloister Court. There is King's Chapel, in which the grandeur of the perpendicular style, especially the windows and fan vaulting, and the glory of the stained glass are unsurpassed anywhere in the world. There is Trinity with its spacious Great Court; and the gentler but no less loveliness of its two smaller neighbours, Trinity Hall and Clare. There is St. John's with its dark Tudor brick, its cobbled courts, and its wide vista over the "Backs" ; Magdalene with its smaller courts and more intimate charm, and its Pepysian Library. Other colleges, though they lack the unique set:ing which the river with its lawns and trees can give. have other features of equal interest both historical and architectural. Christ's has its delightful courts and its memories of John Milton (1625), whose mulberry tree is still standingwith the help and support fitting to one of ripe years. Emmanuel nourished John Harvard, the founder of the American university. There is a fine new court, by Stokes and Drysdale, and behind the older part of the college lie beautiful gardens with lakes and, in the Fellows' Garden, a swimmingbath, the water being originally brought via Hobson's conduits from the Gogs, the chalk hills near by. These conduits are an unusual and attractive feature of the town, flowing as they do down the main thoroughfares of St. Andrews Street and Trumpington Street. The name derives from Thomas Hobson. one-time Mayor of Cambridge, whose " choice "-of a horse in the first instance-gave rise to the phrase. When horses were the only means of transport he kept a large number for hire, but such was his prosperity he could and did dictate to his customers which mount they should ride : they were never allowed to choose-hence "Hobson's choice." His portrait hangs in the Guildhall. Downing College, with which the Downing Chair of Medicine was founded, is noteworthy for its open spacious grounds and its uniform classical style of building, a feature possibly less pleasing to the modern eye than it was to its designers. There is much of interest to be found in the other colleges, but space does not permit their mention here.

\section{Medical Teaching}

The University was recognized in 1318 by a Papal Bull (Pope John XXII), and faculties of divinity, law, and medicine were instituted probably soon after this. In 1421 "Scoles of Fisyk" of some repute were known to exist, because in that year a petition was made to Parliament urging the restriction of practice to those who had graduated in the faculty in their respective universities. It was also then enacted that no woman should be allowed to practise physic-an idea that has been an unconscionable time a-dying, for it was not till over five hundred years later, 1947, that women were admitted to full degrees at Cambridge.

The first M.D. was recorded in 1460 ; M.B. in 1466 . In the sixteenth century there were many M.D.s and M.B.s as well as M.L.s, the latter taken as a qualifying examination. Early in the century Linacre's influence is apparent, for it was at his suggestion that Henry VIII founded the Royal College of Physicians (1518) in London, and in Cambridge the Linacre lectureship at St. John's College. This college was for a long time the chosen training ground for physicians, but towards the middle of the century the fellows were wont to take their duties lightly, and the lectureship came to be regarded as a sinecure. Regius Chairs in Physic, as well as in Divinity, Civil Law. Hebrew, and Greek, were founded in 1540 by Henry VIII, but in spite of this medicine did not prosper for some years. Most of the teaching in physic consisted in expounding the works of Hippocrates, Galen, and Aristaeus. The experimental method was unknown until the eighteenth century, and it was not until much later that our present methods of teaching and examining were begun. From 1570 onwards medical students were no longer required to take Arts before starting their medical course, but even so they usually spent seven years on the M.B. and another five years on the M.D. courses.

The seventeenth century, marked by corruption, sinecures. and poverty of ideas, was followed by some revival of intellectual activity. In 1705 Vigani set up a chemical laboratory 


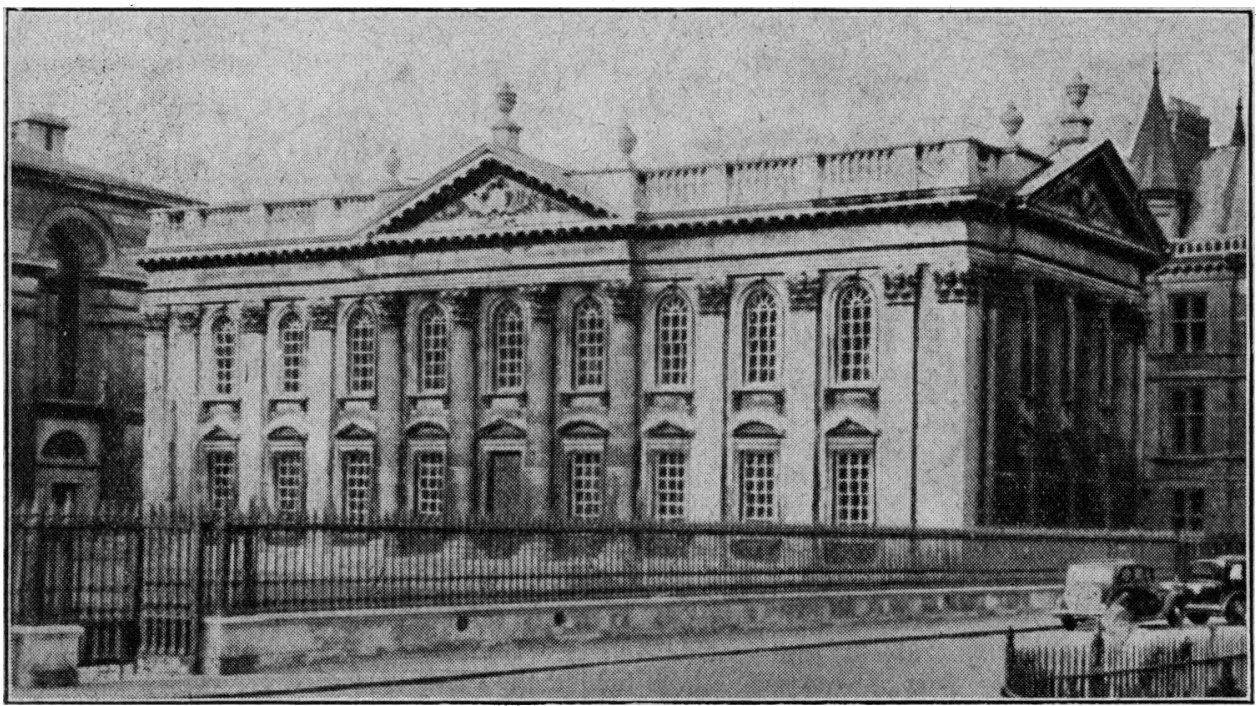

Senate House

[Universtty Cameras

There were at one time two chairs in medicine, the Regius Professorship and the Downing Professorship. The latter was founded about 1800 with the founding of the college of that name, which was at first intended exclusively for the study of medicine and law. But the chair was suspended on the death of Bradbury in 1930 after his thirty-six years' tenure of the office. The first holder was Busick Harwood, who was a Fellow of the Royal Society and much interested in blood transfusion, which he demonstrated on animals. $\mathrm{He}$ was evidently something of a wit and there are several instances recorded. Once on being greeted by Sir Isaac Pennington, the Regius Professor, with, "Good morn-

in Trinity College, and Stephen Hales used this laboratory later for experimental physiology-probably the first physiological laboratory. The health and vitality of the medical school from then on seem closely tied to the growth and development of natural science in the University, especially chemistry, physics, and physiology. Chairs were founded in anatomy, botany, and experimental physiology. In 1734 or thereabouts William Heberden the elder was giving the Linacre Lectures in the anatomy school.

In 1819 lectures on special and general pathology and clinical medicine were started, and from then onwards a period of two years' attendance at a hospital away from Cambridge was required before a candidate could sit the final M.B. This was increased in 1841 to three years, which followed three years' study at Cambridge. In 1842 the practical clinical examination was introduced into the final M.B., and towards the end of the century there were many outward signs of the great increase in size and importance of the school. New chairs were created in physiology (Michael Foster), pathology (C. S. Roy), surgery (George Humphry); and lectureships in botany (Francis Darwin), animal morphology (Adam Sedgwick), physiology (W. H. Gaskell, J. N. Langley, and Sheridan Lee), medicine (Donald McAlister), surgery (G. E. Wherry), midwifery (R. N. Ingle), and medical jurisprudence. This wave of new posts in medical sciences was a clear bid for a full clinical teaching school-probably originating in the mind of Humphry-but many of them were suppressed later and the plan was not allowed to mature.

Queens' College

[University Cameras

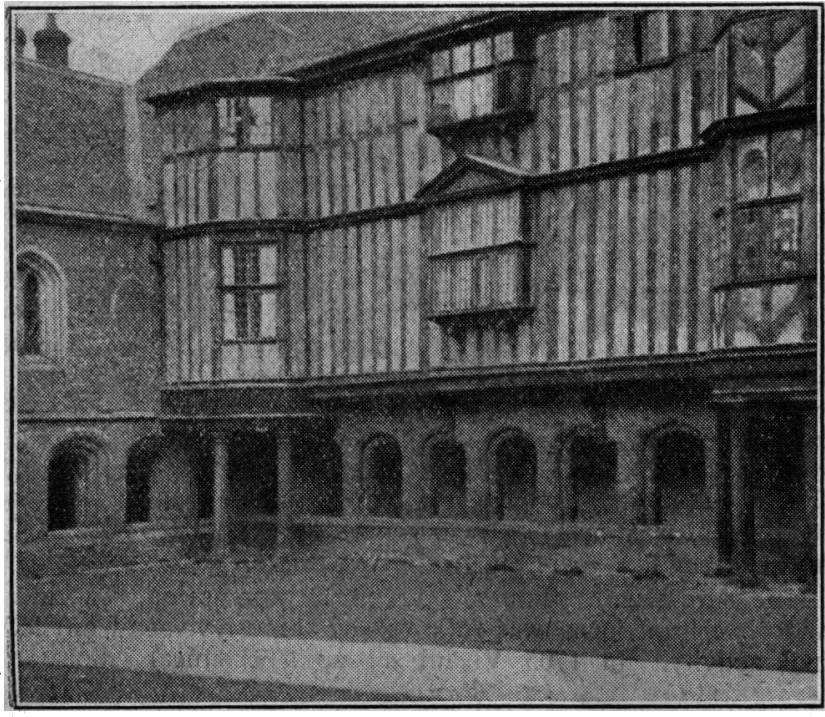

ing, Sir B-U-sick?" he immediately retaliated with, "Sir I-sic ? I never was better in my life!" They were both keen musicians and often played duets together, hence the rhyme:

"Sir Busick, Sir Isaac,

It would make you and I sick,

Sir Isaac, Sir Busick,

To list to your music."

\section{Professors of Medicine}

The first of the twenty-two regius professors was John Blyth, appointed in 1540. Of the earlier holders of the Chair* Francis Glisson (1636) was the most distinguished and is the best known to posterity. He was also President of the Royal College of Physicians and a Fellow of the Royal Society. It was about this time that William Harvey, who had studied at Caius College, Cambridge, but had been engaged in experimental research elsewhere, published his revolutionary findings on the circulation of the blood (1628). Glisson was one of the first of Harvey's contemporaries to accept his views, but like many another of his predecessors and successors he spent much of his time out of Cambridge. He studied and wrote a great deal, and it was his Anatomy of the Liver that left his name to us in "Glisson's capsule," though his work on muscle irritability marked an even more important advance in the field of physiology. He was a fellow of Caius, a college which superseded St. John's as a centre of medical interests. At least seven other regius professors were either scholars or fellows of Caius.

The next outstanding figure in the Chair of Physic did not appear till much later. George Paget (1839 onwards), whose bust is in the Hospital, together with George Humphry and Michael Foster, was largely responsible for the train of events which raised the medical school to its present prosperity and fame. The tradition was further enhanced by his distinguished successors, Clifford Allbutt, Humphry Rolleston, and LangdonBrown. Though no longer with us in the flesh, they are much more than names to hundreds still alive who benefited from their example, their teaching, and their personal friendship.

Allbutt was the first physician practising outside Cambridge to be invited to the Chair. He was shortly after elected a Professorial Fellow of Caius College, at which he had previously been a Scholar and from which he had graduated. His work on cardiovascular disease, visceral neuroses, and many other subjects is well known and forms the foundation of our knowledge in these fields. He also invented the present form of clinical thermometer-a great advance on the 10-inch weapon used for the purpose up to that time. There is a portrait of Allbutt by Orpen in the Fitzwilliam Museum, subscribed for by the medical profession and presented at the last annual meeting of the B.M.A. to be held in Cambridge, in 1920. It is an interesting study, but lacks the warmth and kindliness which

*A point of interest, not generally known, is that there is an actual chair handed down to each new occupant of the post. This chair is now in the Master's Lodge, Downing College, for the use of the present Regius Professor, Sir Lionel Whitby. 
many of his contemporaries saw in him. There is another portrait in the hall of Caius College, perhaps more like him. Rolleston was another with those warm human traits which endeared him to a very wide circle of friends and acquaintances. He had an encyclopaedic knowledge, and was seldom at a loss for a reference however remote and abstruse. His published work is evidence enough of the scope of his interests.

Langdon-Brown's name will probably remain linked with his early interest in the endocrines and the lifelong pursuit of their intricacies, but his death is so recent that his loss is as yet hardly appreciated by the profession, for he remained active until very near the end. He had retired from the Chair in 1936 and was succeeded by John Ryle, who was the first Regius Professor of Physic to be the head of a school of postgraduate clinical research. This marked an important change of policy in the Faculty of Medicine.

\section{Caius and Addenbrooke}

Any review of the Medical School would be incomplete without mention of John Caius and John Addenbrooke, who gave their names respectively to the College and the Hospital. Though Caius was never Regius Professor he played a prominent part in Cambridge medicine as the third founder of the college which has since proved to be the nursery of many eminent and distinguished physicians. He was Master of the College and President of the Royal College of Physicians at the same time, 1558 and onwards. He poured out his wealth in benefactions to the college and wrote much, but, living in turbulent times, he enjoyed little peace in his relatively short term of office. His portrait is to be seen in the college combination room.

Dr. John Addenbrooke, a Fellow of St. Catharine's College, left in his will (1719) a sum of money for the foundation of what was eventually to become the hospital as we know it.

Not obviously a part of the medical school but exerting a powerful influence upon it is the Cavendish Laboratory, with which are associated the world-famous names of J. J. Thomson and Rutherford. Some of their early apparatus can still be seen. In biochemistry, Gowland Hopkins, the father of vitamins, caused in the last quarter of a century a revolution in our ideas on nutrition and metabolism. In pathology, Roy, Canthack, and Woodhead have each in turn added their own contribution to advances in the already high standard of teaching and research in the University and have sent forth their disciples into the medical world to leaven it. In other chairs, Alexander Macalister (Anatomy), Barcroft (Physiology), Nuttall (Parasitology), and many others working with them have carried nn and further raised the high tradition of Cambridge medicine. These departments are housed in modern buildings worthy of their importance, but have been so only within the last twenty years. Till then work that is now classical was being done in dingy, cramped, and utterly inadequate quarters. Even now many of the departments have already outgrown their space and are urgently in need of more buildings.

Addenbrooke's is the key hospital to the new Region which is to include Norfolk, Suffolk, and Cambridgeshire, and it will be linked with the Norfolk and Norwich Hospital and East Suffolk and Ipswich Hospital. With only 350 beds it is no better off than most hospitals serving a similar population. Until twenty years ago it was largely staffed by general practitioners, but since then the staff has consisted entirely of consultants, and the various departments have been brought up to date in order to deal with the increasing demands for consulting work in the area. This new regional development of consulting centres is part of a natural

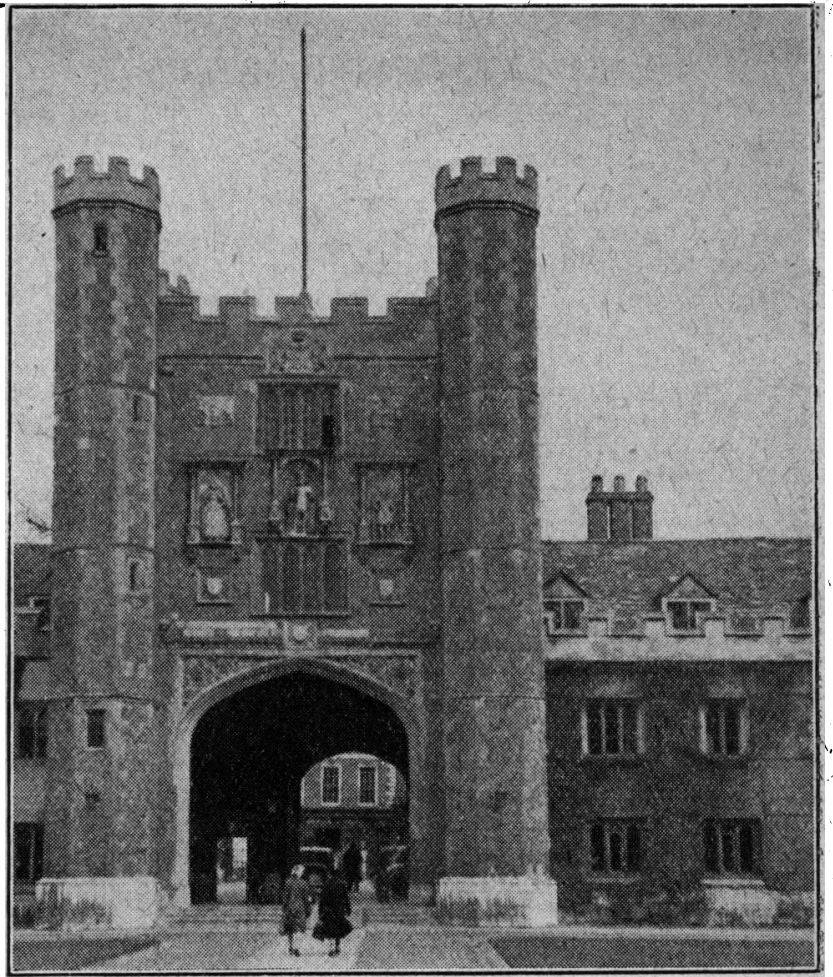

Trunly College Gateway, from Great Court IUniversty Camenas.

process arising not only from the need for treatment nearer the patient's home but still more from the increased complexity in methods of diagnosis and treatment, so that even if they wished the London teaching hospitals could no longer cope with the sheer weight of numbers needing attention. All the special departments are now represented at Addenbrooke's. The pathological services have recently been taken over and expanded by the University Department of Pathology, and there is a University Department of Radiotherapy which is responsible through the professor for both research and therapy. New posts in thoracic surgery and paediatrics have also just been created. Though the mumber of patients handled is smaller, the range of diseases and disorders differs little from what may be seen in London and the larger provincial cities. The plans for a new, comprehensive, modern hospital on a new site to take the place of the old hospital are already well under way.

\section{BIBLIOGRAPHY}

Clark, J. W. (1920). Guide to Cambridge-B.M.A. 88th Annual Meeting. Bowes and Bowes, Cambridge.

Conybeare, Edward (1910). Highways and Byways in Cambridge and Ely. Macmillan, London.

Rolleston, Humphry Davy (1932). The Cambridge Medical School. Cambridge. University Press.

Singer, Charles (1928). A Short History of Medicine. Clarendon Press, Oxford.

King's College and Chapel

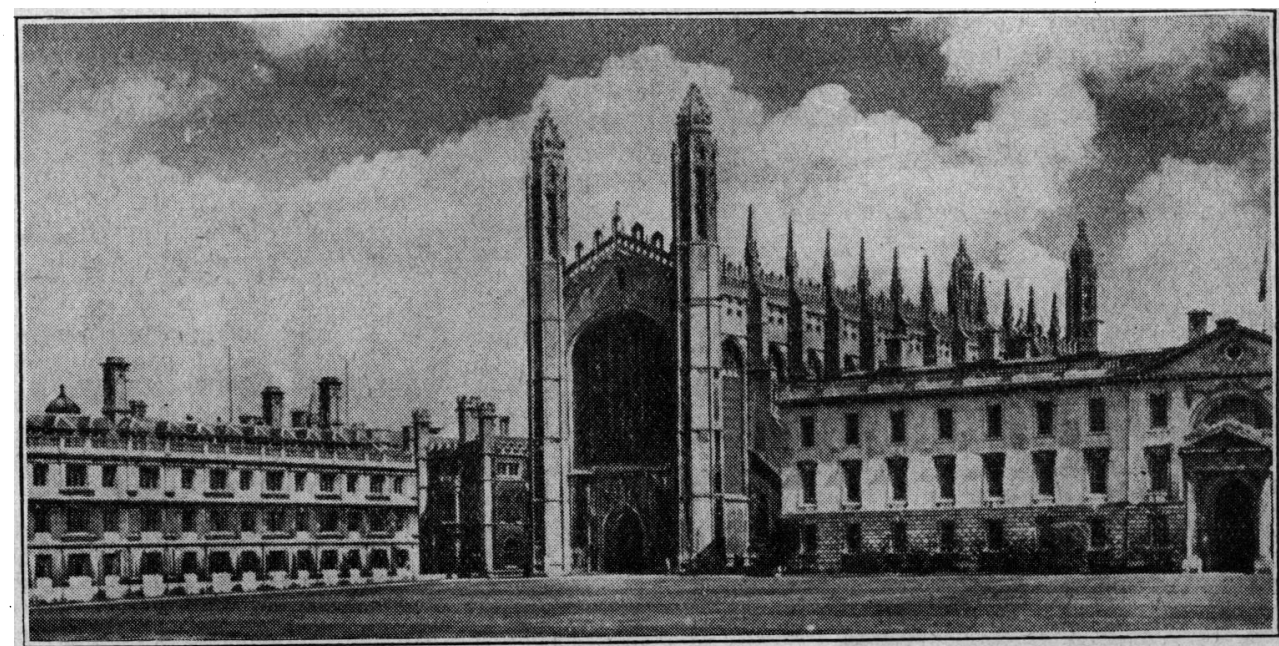




\section{HEARD AT HEADQUARTERS}

\section{"Prescribed Disease"}

The Ministry of National Insurance proposes that when a claim for benefit under the National Insurance (Industrial Injuries) Act is made by a workman on the ground that he is suffering from a "prescribed disease" the claim shall be referred to a practitioner for examination and report. The Ministry is drawing up a list of practitioners to be called upon to undertake these examinations, using at the outset the services of examining surgeons appointed under the Factories Acts. In appropriate cases a consultant will be associated. B.M.A. representatives with representatives of the Association of Certifying Factory Surgeons are in conversation with the Ministry on the fees to be paid for such examinations.

\section{The Aged and Infirm}

The Association's Report on the Care and Treatment of the Elderly and Infirm has been widely circulated (incidentally to every member of Parliament), and both its formal and its popular editions have been welcomed. The Committee, however, has not ceased its work, and it is reassembling, after almost a year's intermission, to consider how to further its previous recommendations. One of the reports which it has before it is an excellent document prepared by a committee of the Liberal Party, which will come before the party conference at Blackpool this month. One member of the B.M.A. Committee, Lord Amulree, is also a member of the committee which prepared the Liberal Party report. The Committee has also a report by one of its members, Dr. E. B. Brooke, on the place of the out-patient department in caring for old people. Dr. Brooke believes that an important part could be played by the out-patient department in any co-ordinated scheme. With the help of the almoners and the department of physical medicine, and a transport organization, it would not only assist the old people but would lessen the strain on hospital beds.

\section{Income Tax Deductions}

Possibly income tax inspectors are not as indulgent on this side of the Atlantic as they are on the other, but here is a list of items which a medical journal in the U.S.A. publishes as the major income tax deductions which the Government allows doctors : amounts paid for preparation of tax returns and estimates and auditing generally; motor-car costs ; bad debts ; business expenses; club subscriptions if necessary to maintain professional contacts ; expenses incurred in collecting professional accounts ; contributions (up to $15 \%$ of gross income) to charitable, educational, scientific, and other organizations; cost of travel to and from conventions, and subsistence ; depreciation on professional property; entertainment costs incurred to benefit practice ; equipment, such as books, instruments, etc. ; gifts, if made to benefit practice (such as candy, cigars, flowers); interest on loans and mortgages; insurance premiums; journals ; litigation expenses in connexion with practice; licence fees, medical or driving; losses not covered by insurance ; maintenance cost of surgery; medical society subscriptions; moving expenses; rent for professional quarters; repairs ; salaries to secretaries and other employees; dressings, drugs, vaccines. etc.; office supplies ; certain taxes (other than ircome tax itself !); and telephone and telegraph costs. It looks as though, instead of any tax being payable when all these deductions have been made, the income tax authorities will have to make a handsome contribution to the doctor.

\section{TRADE UNION MEMBERSHIP}

The following is a list of local authorities which are understood to require employees to be members of a trade union or other organization :

Metropolitan Borough Councils.-Fulham, Hackney, Poplar. Non-County Borough Councils.-Dartford, Radcliffe (limited to future appointments), Tottenham, Wallsend.

Urban District Councils.-Denton, Droylsden, Houghton-leSpring, Huyton-with-Roby, Portslade, Redditch (restricted to new appointments), Tyldesley.

Scottish Burghs.-Motherwell and Wishaw.

\section{Correspondence}

\section{Welsh Association of Hospital M.O.s}

SIR,-An association of full-time hospital medical officers has been formed within the Welsh Region as the result of the following considerations.

In the past the interests of hospital medical officers have been the concern of the Society of Medical Officers of Health, the Association of Medical Superintendents, and the Association of Municipal Specialists, acting through the British Medical Association. The impending separation of medical officers of health from hospital activities makes opportune the formation of a directly representative association to promote the interests of full-time hospital medical officers and to be available within the region for consultation in all aspects of hospital practice. The Association is called the Association of Hospital Medical Officers (Welsh Region), and membership is open to medical superintendents, consultants and specialists, and medical officers of registrar grade and above. Associate membership is open to junior medical officers of hospitals.

It is hoped that other regions will form similar associations and that these will ultimately amalgamate to form a national body having a recognized status within the British Medical Association. The Secretary will be pleased to hear from regions where similar activities are contemplated or are actually in being.-I am, etc.,

East Glamorgan County Hospital.

Church Village. Pontypridd.

P. T. BRAY Secretary

\section{Petrol Ration}

SIR,--It is to be hoped that the Association will protest against the proposed cut in the allowance of "essential" petrol to counteract the basic ration. This is the more necessary as our recent applications have been drastically cut, presumably because the superior persons employed by the Ministry of Fuel regard us as rogues and vagabonds and not worth a tinker's cuss.-I am, etc.,

H. E. Gibson.

\section{H.M. Forces Appointments}

Maior-General N. Cantlie, C.B., M.C., K.H.P., late R.A.M.C., to be Lieutenant-General.

Colonels (Temporary Major-Generals) F. Harris, C.B.E., M.C., K.H.S., and K. A. M. Tomory, O.B.E., and Colonels O. C. Link, A. E.' Richmond, C.B.E., K.H.S., T. Young, O.B.E., F. R. H, Mollan, O.B.E., M.C., D. Fettes, O.B.E., K.H.S., T. Menzies, O.B.E., H. T. Findlay, and J. Bennet, K.H.P., late R.A.M.C., to be Brigadiers.

Colonel (Temporary Major-General) J. J. Magner, M.C., late R.A.M.C., to be Major-General.

Colonel S. Smith, late R.A.M.C., has retired on retired pay.

Colonel J. T. Simson, retired, re-emplnyed, late R.A.M.C., on ceasing to be emploved has reverted to retired pay.

Lieutenant-Colonels E. P. N. Creagh, G. E. MacAlevey, C.B.E., D.S.O., M.C.. C. P. Chambers, and V. J. Perez, O.B.E., from R.A.M.C., to be Colonels.

\section{ROYAL ARMY MEDICAL CORPS}

Mainr H. M. Alexander having attained the age limit for retirement is retained on the Active List (Supernumerary).

Captains H. Foster, J. Duguid, and J. N. Threlfall to be Majors. Captain T. C. R. Archer, from Short Service Commission, to be Captain, retaining his present seniority.

Short Service Commission.-Lieutenant A. W. Morrow, from Emergency Commission, to be Lieutenant.

\section{REGULAR ARMY RESERVE OF OFFICERS Royal Army Medical Corps}

Major S. H. Smith, M.C., having exceeded the age limit of liability to recall, has ceased to belong to the Reserve of Officers.

Captain (Brevet Major) B. Malaher, having exceeded the age limit of liability to recall, has ceased to belong to the Reserve of Officers on account of disability. 
TERRITORIAL ARMY

\section{Royal Army Medical Corps}

Niajor S. W. Barber has been granted the acting rank of Lieutenant-Colonel.

Captain (War Substantive Lieutenant-Colonel) J. L. Lovibond to be Major.

Captains (War Substantive Majors) F. V. Allen, O.B.E., W. H. Valentine (from R.A.R.O.), S. S. Chesser, and F. J. Fowler to be Majors.

Captains A. Wilcox, A. H. M. Richards, T. MacGregor-Gibson, J. MacM. Macfie, and N. H. H. Longton to be Majors.

Lieutenants (War Substantive Majors) G. Y. Feggetter and H. J. Croot, from Emergency Commissions, to be Captains, and have been granted the acting rank of Lieutenant-Colonel.

Lieutenants (War Substantive Cap.ains) J. R. Macintyre and D. T Rowlands, from Emergency Commissions, to be Captains, and have been granted the acting rank of Major.

Lieutenants (War Substantive Captains) S. A. Bower, M. A. Watson, G. R. Cubitt, A. H. Bulleid, D. E. Marmion, G. H. Sanderson, W. J. Atkinson, E. J. Williams, G. V. Cole, H. J. Gilbert, A. A. Pow, R. B. Raffle, G. H. A. Robinson, R. McL. Archibald, and J. G. A. Gilruth, from Emergency Commissions, to be Captains.

Lieutenant (War Substantive Captain) C. D. Rigg to be Captain.

\section{LAND FORCES: EMERGENCY COMMISSIONS}

Royal Army Medical Corps

War Substantive Major A. A. G. Lewis has relinquished his commission on account of disability and has been granted the honorary rank of Lieutenant-Colonel.

War Substantive Captain E. C. Fernandes has relinquished his commission and has been granted the honorary rank of Major.

War Substantive Captains M. Singh and G. A. Sharpe have relinquished their commissions and have been granted the honorary rank of Captain.

Lieutenant T. J. Anthony to be Captain.

R. A. Roberts to be Lieutenant.

\section{WOMEN'S FORCES}

EMPLOYED WITH THE R.A.M.C

Captain M. D. Cameron has relinquished her commission on account of disability and has been granted the honorary rank of Captain.

\section{ROYAL AIR FORCE}

Air Commodore P. C. Livingston, C.B., C.B.E., A.F.C., to be Air Vice-Marshal.

Group Captain P. A. Hall has reverted to the retired list retaining the rank of Air Commodore.

Group Captain G. H. H. Maxwell has retired.

Wing Commanders J. Magner, R. G. Freeman, and P. B. L. Potter,

O.B.E., to be Group Captains (Substantive).

Squadron-Leaders R. D. Bruce, A. B. Marshall, F. V. Maclaine,

R. C. O'Grady, S. Paul, R. L. Scott, and E. B. Harvey to be Wing Commanders (Substantive).

To be Squadron-Leaders: I. W. H. R. Cran, D. Stevenson, M.B.E., J. C. Bowe, and D. W. Boatman.

To be Fhight-Lieutenants: M. Alms, G. Ansell, G. R. Carr, K. N. V. Palmer, B. H. Pickard, R. D. Poole, H. Wainstead, J. A Wheeler-Bennett, J. A. Cooney, C. J. W. Soutar, E. S. Odbert, A. E. Carter, L. Wolman, and P. J. Macnamara

Flight-Lieutenants (Substantive) $R$. Mortimer and D. Stevenson, M.B.E., have relinquished the war substantive rank of Squadron-

Leader.

Flying Officer P. D. Sutton, M.B.E., to be Flight-Lieutenant.

To be Flying Officers: T. C. L. Brown and seconded to the Hospital of St. Cross, Rugby; A. R. P. Calder and seconded to St. Thomas's Hospital.

To be Flying Officers: J. W. Baker, R. E. Blakey, C. I. Cooling, J. G. Hamilion, M. J. Hargrave, T. K. Lamballe, F. I. Locke, R G. C Maclaren, R. J. Smith, P. J. Banks, D O Davies, I. D Findlay, J. J. Fingard, G. W. Korn, R. J. Moylan-Jones, T. N. Riley, P. Sattin, and J. Whitwell.

\section{Royal Auxiliary Air Force}

D. Turner to be Flight-Lieutenant in the reconstituted R.A.A.F

Royal Air force Volunteer Reserve

Flight-Lieutenants R. N. Houlding and D. H. Fowler have esigned their commissions retaining the rank of Squadron-Leader.

Flight-Lieutenant W. E. Robinson has relinquished his commission on account of medical unfitness for Air Force service retaining his rank.

D. W. James to be War Substantive Flight-Lieutenant

Fiying Officers H. M. Kent, G. N. Beck, A. W. Halfhide, D. P. Howarth, H. E. M. Kay, D. M. Kerslake, C. McIver, J. K. Oates, A. T. Richardson, K. G. Paddle, F W. R. Seward, D. W. Stuart, T. F. Waters, R. R. Davis, A. J. Fouracre, N. L. Gilburn, J. Hegarty M. S. Hughes. G. A. S. Lloyd, W. Lyons. E. P. Mackenzie, R. W. W Watson, and R. D. Watson, to be Flight-Lieutenants (Substantive)

The notification concerning E. S. Odbert in a Supplement to the London Gazette dated Jan. 20, p 500, col. 2, has been cancelled.
The notification concerning J. McA. Tagrant in a Supplement to the London Gazelte dated Jan. 27, p. 656, col. 1, should have read J. MicA. Taggart.

The notification concerning J. W. Moffitt in a Supplement to the Lonaon Gazette dated Feb. 17, p. 1118, col. 1, should have read J. W. R. Moffit.

The notification concerning G. I. Tewfik in a Supplement to the London Gazette dated Jan. 27, p. 656, col. 1, has been cancelled.

Flying Officers G. I. Tewfik and L. W. Oxenham have relinquished their commissions on account of medical unfitness for Air Force service, retaining their rank.

\section{WOMEN'S FORCES}

Employed with the Medical Branch of the R.A.F.

Flying Officers J. H. Kelly and M. A. McGrath to be FlightLieutenants.

The following have been granted the substantive rank of FlightLieutenant: E. C. Baird, B. D. Lee, M. E. McClelland, E. M. McKechnie, E. M. I. Milne, L. G. Moore, M. Robertson, E. M. D. M. Scott, M. E. G. Sherwell, and E. D. L. Simpson

\section{B.M.A. LIBRARY}

The following books have been added to the Library :

Altenburg, E.: Genetics. 1945

Bach, T. F. (Editor): Arthritis and Related Conditions. 1947.

Bankoff, G.: The Conquest of Brain Mysteries. 1947.

Carr, M. W.: Dentistry, and agency of health service. 1946

Coope, R.: Diseases of the Chest. Second edition. 1948.

Daley, R., and Miller, H. G. (Editors): Progress in Clinical Medicine. 1948 .

Das, K.: Clinical Methods in Surgery. 1947.

Dearden, H. : Creation's Heir. 1947.

Denny-Brown, D.: Handbook of Neurological Examination and Case Recording. 1946.

Donaldson, J. K.: Surgical Disorders of the Chest. Second edition. 1947.

Gifford, S. R.: Handbook of Ocular Therapeutics. Fourth edition revised by D. Vail. 1947.

Gilberg, A.: Eskimo Doctor.' 1948.

Graves, C.: The Story of St. Thomas's, 1106-1947. 1947.

Hale-White, W.: Materia Medica. Twenty-seventh edition revised by A. H. Douthwaite. 1947.

Harris, D. T.: Practical Histology for Medical Students. Fourth edition. 1947

Hill, H.: Pasteurization. Second edition. 1947.

Ikin, A. E., and Oates, G. E.: A General Course in Hygiene. Third edition revised by H. A. Nathan. '1947.

Keffer, L.: Indice Bibliográfico de Lepra. Vol. 2. 1947.

Knudsen, K. A.: Textbook of Gymnastics. Second edition, vol. I. 1947.

Lewin, P.: The Foot and Ankle. Third edition. 1947.

Lickley, J. D.: An Introduction to Gastro-enterology. 1947

McAllister, J. B.: Ethics, with special application to the nursing profession. 1947.

McCormick, C. O.: Textbook on Pathology of Labor, the Puerperium and the Newborn. Second edition. 1947.

Neustatter, W: L.: Modern Psychiatry in Practice. Second edition. 1948 .

New York Academy of Medicine: Medicine in the Changing Order 1947.

Parsons, Sir J. H., and Duke-Elder, Sir S.: Diseases of the Eye Eleventh edition. 1948.

Paterson, D., and Smith, J. F.: Modern Methods of Feeding in Infancy and Childhood. Ninth edition. 1947.

Romanis, W. H. C., and Mitchiner, P. H.: Science and Practice of Surgery. Eighth edition, two vols. 1948.

Ryle, J. A.: The Natural History of Disease. Second edition. 1948.

Sammartino, E. S.: Tratado Practico de Hemoterapia. 1947.

Sante, L. R.: Manual of Roentgenological Technique. Fourteenth edition. 1947.

Sante, L. R.: Principles of Roentgenological Interpretation. Seventh edition. 1947.

Selinger, E.: Office Treatment of the Eye. 1947.

Smith, E. A.: A Manual on Dental Metallurgy. Sixth edition. 1947.

Smitskamp, H.: A Neuro-vascular Syndrome Related to Vitamin Deficiency. 1947.

Stoke, J. E.: Secretarial Practice and Office Administration for Hospitals. 1947

Stokvis, B.: Psychologie der Suggestie en Autosuggestie. 1947.

Tetau, J.: Homéopathie. Second edition revised by L. A. Rousseau and $H$. Deroche. 1947.

Tredgold, A. F.: Textbook of Mental Deficiency (Amentia). Seventh edition. 1947

Troup, W. A.: Therapeutic Uses of Infra-red Rays. Fourth edition. 1947.

Vallejo, E. A.: Disfunciones Motoras del Estomago. 1947.

\section{RETURN TO PRACTICE}

The Central Medical War Committee announces that Dr. Clifford G. Parsons, F.R.C.P., has resumed civilian practice at 89 , Harborne Road, Edgbaston, Birmingham. 


\section{Association Notices}

\section{SiR Charles hastings Clinical prize}

The Sir Charles Hastings Clinical Prize, which consists of a certificate and a money award of $\mathbf{5 0}$ guineas, is again open for competition. The following are the regulations governing the award :

1. The prize is established by the Council of the British Medical Association for the promotion of systematic observation, research and record in general practice; it includes a money award of the value of 50 guineas.

2. Any member of the Association who is engaged in general practice is eligible to compete for the prize.

3. The work submitted must include personal observations and experiences collected by the candidate in general practice, and a high order of excellence will be required. If no essay entered is of sufficient merit no award will be made. It is to be noted that candidates in their entries should confine their attention to their own observations in practice rather than to comments on previously published work on the subject, though reference to current literature should not be omitted when it bears directly on their results, their interpretations, and their conclusions.

4. Essays, or whatever form the candidate desires his work to take, must be sent to the British Medical Association House, Tavistock Square, London, W.C.1, not later than Dec. 31, 1948 The prize will be awarded at the Annual General Meeting of the Association to be held in 1949 .

5 . No study or essay that has been published in the medical press or elsewhere will be considered eligible for the prize, and a contribution offered in one year cannot be accepted in any subsequent year unless it includes evidence of further work. A prizewinner in any year is not eligible for a second award of the prize.

6. If any question arises in reference to the eligibility of the candidate or the admissibility of his or her essay the decision of the Council on any such point shall be final.

7. Each essay must be typewritten or printed, must be distinguished by a motto, and must be accompanied by a sealed envelope marked with the same motto, and enclosing the candidate's name and address.

8. The writer of the essay to whom the prize is awarded may, on the initiative of the Science Committee, be requested to prepare a paper on the subject for publication in the British Medical Journal or for presentation to the appropriate Section of the Annua Meeting of the Association.

9. Inquiries relative to the prize should be addressed to the Secretary.

\section{KATHERINE BISHOP HARMAN PRIZE}

The Council of the B.M.A. is prepared to consider an award of the Katherine Bishop Harman Prize of the value of $£ 75$ in 1949 The purpose of the prize, which was founded in 1926, is to encourage study and research directed to the diminution and avoidance of the risks to health and life that are apt to arise in pregnancy and child-bearing. It will be awarded for the best essay submitted in open competition, competitors being left free to select the work they, wish to present, provided this falls within the scope of the prize. Any medical practitioner registered in the British Empire is eligible to compete.

Should the Council of the Association decide that no essay submitted is of sufficient merit, the prize will not be awarded in 1949 , but will be offered again in the year next following this decision, and in this event the money value of the prize on the occasion in question will be such proportion of the accumulated income as the Council shall determine.

The decision of the Council will be final

Each essay must be typewritten or printed in the English language, must be distinguished by a motto, and must be accompanied by a sealed envelope marked with the same motto and enclosing the candidate's name and address. Essays must be forwarded so as to reach the Secretary, to whom all inquiries should be addressed, at B.M.A. House, Tavistock Square, London, W.C.1, not later than Dec. 31, 1948.

\section{MIDDLEMORE PRIZE}

The Middlemore Prize consists of a cheque for $£ 50$ and an illuminated certificate, and was founded in 1880 by the late Richard Middlemore, F.R.C.S., of Birmingham, to be awarded for the best essay or work on any subject which the Council of the British Medical Association may from time to time select in any department of ophthalmic medicine or surgery. The Council is prepared to consider the award of the prize in the year 1949 to the author of the best essay on "The Value of Orthoptics in the Treatment of Squint." Essays submitted in competition must reach the Secretary, British Medical Association, B.M.A. House Tavistock Square, London, W.C.1, on or before Dec. 31, 1948. Each essay must be signed with a motto and accompanied by a sealed envelope marked on the outside with the motto and containing the name and address of the author. In the event of no essay being of sufficient merit the prize will not be awarded in 1949.

\section{PRIZES FOR NURSES}

The Council of the British Medical Association is prepared to consider the first award in 1948 of three prizes each of the value of 20 guineas for the best essay and three prizes each of the value of 10 guineas for the second best essay submitted in open competition by each of the following categories of nurses: (i) Pupil nurses ; (ii) State registered nurses working in a hospital; (iii) State registered nurses not working in a hospital-i.e., district nurses, private nurses, etc.

The subjects of the essays for 1948 shall be: Category (i) "Suggested Improvements in the Methods of Training Nurses", Category (ii) "Nursing the Patient, not the Disease: the NursePatient Relationship"; Category (iii) "Difficulties of Nursing in the Patient's own Home and their Solution."

The purpose of these prizes is the promotion of systematic observation among nurses. In awarding the prizes due regard will be given to evidence of personal observation. No essay that has previously appeared in the medical press or elsewhere will be considered eligible for a prize. Nurses who are undergoing a course of training at a hospital are eligible to compete under category (i); nurses registered by the General Nursing Council are eligible to compete under categories (ii) and (iii). If any question arises in reference to the eligibility of a candidate or the admissibility of his or her essay, the decision of the Council of the British Medical Association shall be final. Should the. Council decide that no essay entered is of sufficient merit, no award shall be made. Each essay must be typewritten or legibly written, must be unsigned, and have attached to it a sealed envelope containing the name and address of the candidate and the category into which he or she falls. Essays must be forwarded so as to reach the Secretary of the British Medical Association not later than May 31, 1948. Inquiries about the prizes should be addressed to the Secretary, British Medical Association, B.M.A. House, Tavistock Square, London, W.C.1.

\section{Charles Hill,}

Secretary.

\section{GROUP OF VENEREOLOGISTS}

A meeting of the recently formed Group of Venereologists will be held at B.M.A. House, Tavistock Square, London, W.C.1, on Friday, May 7, 1948, at 2 p.m.

The Group consists of all those members of the Association who are engaged predominantly in the practice of venereology. The agenda will consist of $(a)$ the election of a chairman; (b) consideration of the size and constitution of the Group Committee ; and (c) a general discussion on the work of the Group.

Charles Hill, Secretary.

\section{Diary of Central Meetings} MAY

5. Wed. Council, 11 a.m.

Branch and Division Meetings to be Held

Metropolitan Counties Branch.-At B.M.A. House, Tavistock Square, London, W.C., Tuesday, June 1, 2.30 p.m. Ninetieth Annual General Meeting. Agenda : Report of Branch Council for 1947-8; report of Branch representatives on Central Council, 1947-8; election of officers for 1948-9; address by incoming President.

\section{Meetings of Branches and Divisions}

\section{Coventry Division}

A joint meeting of the Coventry and the Nuneaton and Tamworth Divisions was held in the Coventry and Warwickshire Hospital on April 13. The meeting was the occasion of a visit to the Divisions of the Clinical and Pathological Section of the B.M.A. Birmingham Branch. Cases were demonstrated by Prof. A. P. Thomson, Prof. $\mathrm{K}$. D. Wilkinson, Mr. Hugh Donovan, Mr. J. L. Collis, and $\mathrm{Mr}$. Nisbett, to all of whom an enthusiastic vote of thanks was approved on the motion of Dr. Murray Bladon, of Coventry, seconded by Dr. Procery, of Atherstone.

The address of the North-west Metropolitan Regional Hospital Board is 11a, Portland Place, London, W.1 (Tel.: Museum 9575/9). 